\title{
Kinetics and thermodynamic properties related to the drying of 'Cabacinha' pepper fruits
}

\author{
Hellismar W. da Silva ${ }^{1}$, Renato S. Rodovalho ${ }^{2}$, Marya F. Velasco ${ }^{2}$, Camila F. Silva ${ }^{2}$ \& Luís S. R. Vale ${ }^{2}$ \\ ${ }^{1}$ Universidade Federal de Lavras. Lavras, MG. E-mail: waksonhellismar@gmail.com (Corresponding author) \\ ${ }^{2}$ Instituto Federal Goiano - Câmpus Ceres. Ceres, GO. E-mail: renato.rodovalho@ifgoiano.edu.br; marya.velasco@hotmail.com; camilaifgoiano@hotmail.com; \\ luissergiovale@hotmail.com
}

\section{Key words:}

Capsicum chinense L.

moisture ratio

enthalpy

activation energy

\begin{abstract}
A B S T R A C T
The objective of this study was to determine and model the drying kinetics of 'Cabacinha' pepper fruits at different temperatures of the drying air, as well as obtain the thermodynamic properties involved in the drying process of the product. Drying was carried out under controlled conductions of temperature $\left(60,70,80,90\right.$ and $\left.100^{\circ} \mathrm{C}\right)$ using three samples of $130 \mathrm{~g}$ of fruit, which were weighed periodically until constant mass. The experimental data were adjusted to different mathematical models often used in the representation of fruit drying. Effective diffusion coefficients, calculated from the mathematical model of liquid diffusion, were used to obtain activation energy, enthalpy, entropy and Gibbs free energy. The Midilli model showed the best fit to the experimental data of drying of 'Cabacinha' pepper fruits. The increase in drying temperature promoted an increase in water removal rate, effective diffusion coefficient and Gibbs free energy, besides a reduction in fruit drying time and in the values of entropy and enthalpy. The activation energy for the drying of pepper fruits was $36.09 \mathrm{~kJ} \mathrm{~mol}^{-1}$.
\end{abstract}

\section{Palavras-chave: Capsicum chinense L. razão de umidade entalpia energia de ativação}

\section{Cinética e propriedades termodinâmicas relacionadas à secagem dos frutos de pimenta Cabacinha}

\section{R E S U M O}

Objetivou-se, neste trabalho, determinar e modelar a cinética de secagem dos frutos de pimenta Cabacinha para diferentes temperaturas do ar de secagem, bem como obter as propriedades termodinâmicas envolvidas no processo de secagem do produto. A secagem foi realizada em condições controladas de temperatura $\left(60,70,80,90\right.$ e $\left.100{ }^{\circ} \mathrm{C}\right)$ utilizandose três amostras de $130 \mathrm{~g}$ de frutos, as quais foram pesadas periodicamente até atingirem massa constante. Os dados experimentais foram ajustados a diferentes modelos matemáticos frequentemente utilizados na representação da secagem de frutos. O coeficiente de difusão efetivo, calculado a partir do modelo matemático da difusão líquida, foi utilizado para obtenção da energia de ativação, entalpia, entropia e energia livre de Gibbs. O modelo de Midilli foi o que apresentou os melhores ajustes aos dados experimentais da secagem dos frutos de pimenta Cabacinha. A elevação da temperatura de secagem promoveu: o aumento nos valores da taxa de remoção de água dos frutos, do coeficiente de difusão efetivo e da energia livre de Gibbs além de redução no tempo de secagem dos frutos, nos valores da entalpia e a entropia. A energia de ativação para a secagem dos frutos de pimenta foi de $36,09 \mathrm{~kJ} \mathrm{~mol}^{-1}$. 


\section{INTRODUCTION}

The varieties of the pepper species Capsicum chinense L. stand out for their great diversity of fruits with different forms, flavors, aromas, pungencies and chemical compositions. These characteristics justify their wide use in human consumption, medicine and cosmetic industries (Dagnoko et al., 2013).

The pepper market is characterized for being very diversified, since the fruits are commercialized fresh and processed, in sauces, picklings and seasonings (Henz \& Moretti, 2008). Kaleemullah \& Kailappan (2004) point out that, for being stored with high water contents, pepper and bell pepper fruits may suffer physico-chemical and biological alterations, thus reducing the commercial value of the product (Henz \& Moretti, 2008).

The drying of agricultural and food products has been one of the strategies adopted and successfully used in the conservation of the quality of various products. Drying pepper fruits, for instance, allows reducing the high water contents to levels adequate for storing, which consequently decreases biological activity in the fruits and the problems regarding deterioration and contamination (Srinivasakannan \& Balasubramanian, 2009).

The knowledge on the thermodynamic properties, which include enthalpy, entropy and Gibbs free energy, related to the process of drying of agricultural products, provides information necessary to project drying devices, study the properties of the absorbed water (Corrêa et al., 2010) and calculate the necessary energy demand in drying processes (Martins et al., 2015).

Enthalpy provides a measurement of the variation of the binding energy between water molecules and the constituents of the product during the process of sorption (Jideani \& Mpotokwana, 2009). Entropy is related to the degree of disorder (Goneli et al., 2010), i.e., it is associated with the spatial arrangement of the water-product relationship (Jideani \& Mpotokwana, 2009). Gibbs free energy, on the other hand, is a parameter used in the evaluation of spontaneity of water desorption (Corrêa et al., 2010).

Based on the above, this study aimed to determine and model the drying kinetics of 'Cabacinha' pepper fruits and obtain the thermodynamic properties involved in the drying process of the product.

\section{Material ANd Methods}

The study was conducted at the Laboratory of Seed Analysis (LAS) of the Federal Institute of Education, Science and Technology of Goiás - Campus Ceres (IF Goiano - Câmpus Ceres), in the municipality of Ceres-GO, Brazil.

'Cabacinha' pepper fruits (strain IFET 1541) were used in the experiment, which were manually harvested at maturation (Henz \& Moretti, 2008), defined by their orange color. The fruits were washed in running water and selected, discarding the ones with injuries; then, they were placed in plastic bags and maintained in a refrigerator (temperature of $4.20 \pm 0.72$ and $66.2 \pm 5.10 \%$ of relative air humidity - $\mathrm{RH}$ ), until the drying process (Reis et al., 2011).
The water content in the fruits was determined by the standard oven method, at $103 \pm 1^{\circ} \mathrm{C}$ for $24 \mathrm{~h}$, in four replicates (ASABE, 2010).

The fruits were dried in a forced-air oven adjusted to temperatures of $60,70,80,90$ and $100{ }^{\circ} \mathrm{C}$, with respective $\mathrm{RH}$ values of $10.5,6.6,4.5,2.8$ and $2.2 \%$. For the drying temperature, three metallic trays (dimensions: $26.7 \mathrm{~cm}$ long, $9.7 \mathrm{~cm}$ wide and $7.2 \mathrm{~cm}$ high) were filled with $130 \mathrm{~g}$ of product, forming a single layer with thickness of approximately $9.5 \mathrm{~cm}$. During the drying process, the water content of the fruits was gravimetrically monitored, by weighing the samples periodically on an analytical scale (resolution of $0.01 \mathrm{~g}$ ) until they reached the water content at hygroscopic equilibrium, i.e., when the variation in the mass of the containers did not exceed $0.01 \mathrm{~g}$ in three consecutive weighings (Corrêa et al., 2010).

Water removal rate (WRR) of 'Cabacinha' pepper fruits was calculated using Eq. 1.

$$
\mathrm{WRR}=\frac{\mathrm{Mw}_{0}-\mathrm{Mw}_{\mathrm{i}}}{\mathrm{Md} \cdot\left(\mathrm{t}_{\mathrm{i}}-\mathrm{t}_{0}\right)}
$$

where:

WRR - water removal rate, $\mathrm{kg} \mathrm{kg}^{-1} \mathrm{~h}^{-1}$;

$\mathrm{Mw}_{0}$ - previous total mass of water, $\mathrm{kg}$;

$\mathrm{Mw}_{\mathrm{i}}$ - current total mass of water, kg;

Md - mass of dry matter, kg;

$t_{0} \quad$ - previous total time of drying, $h$; and

$t_{i} \quad$ - current total time of drying, $h$.

For the determination of moisture ratios (RX) during the drying process under different conditions of temperature and relative air humidity, the following expression was used (Santos et al., 2012; Morais et al., 2013):

$$
\mathrm{RX}=\frac{\mathrm{X}-\mathrm{X}_{\mathrm{e}}}{\mathrm{X}_{\mathrm{i}}-\mathrm{X}_{\mathrm{e}}}
$$

where:

X - water content of the product, decimal (d.b.);

$\mathrm{X}_{\mathrm{i}} \quad$ - initial water content of the product, decimal (d.b.); and

$\mathrm{X}_{\mathrm{e}} \quad$ - water content at hygroscopic equilibrium of the product, decimal (d.b.).

Moisture ratio data were used for the adjustment of 10 mathematical models, employed to represent the drying of different types of fruits (Vega et al., 2007; Pontes et al., 2009; Corrêa et al., 2010; Reis et al., 2011; Moraes et al., 2013), according to the expressions in Table 1.

For the adjustment of the mathematical models, a nonlinear regression analysis was performed through the GaussNewton method. The degree of adjustment of each model was verified considering the magnitude of the adjusted coefficient of determination $\left(\mathrm{R}^{2}\right)$, standard deviation of estimate (SE), residual sum of squares (RSS) and the tendency of residual distribution (Goneli et al., 2011; Reis et al., 2011; Moraes et al., 2013). SE and RSS were calculated using the following expressions, respectively: 
Table 1. Mathematical models used to predict the drying phenomenon

\begin{tabular}{|c|c|c|}
\hline Model designation & Model & $n^{\circ}$ \\
\hline Approximation of Diffusion & $R X=a \exp (-k t)+(1-a) \exp (-k b t)$ & (3) \\
\hline Two-Term & $R X=a \exp (-k t)+b \exp (-c t)$ & (4) \\
\hline Logarithmic & $R X=a \exp (-k t)+b$ & (5) \\
\hline Midilli & $R X=a \exp \left(-k t^{b}\right)+c t$ & (6) \\
\hline Modified Midilli & $R X=\exp \left(-k t^{n}\right)+a t$ & (7) \\
\hline Newton & $R X=\exp (-k t)$ & (8) \\
\hline Page & $R X=\exp \left(-k t^{n}\right)$ & (9) \\
\hline Modified Page & $R X=\exp \left(-(k t)^{n}\right)$ & (10) \\
\hline Verna & $R X=a \exp (-k t)+(1-a) \exp (-b t)$ & (11) \\
\hline Wang and Singh & $\mathrm{RX}=1+(\mathrm{at})+\left(\mathrm{bt}^{2}\right)$ & (12) \\
\hline
\end{tabular}

$$
\begin{aligned}
\mathrm{SE} & =\sqrt{\frac{\sum_{\mathrm{i}=1}^{\mathrm{n}}(\mathrm{Y}-\hat{\mathrm{Y}})^{2}}{\mathrm{DF}}} \\
\mathrm{RSS} & =\frac{1}{\mathrm{n}} \cdot \sum_{\mathrm{i}=1}^{\mathrm{n}}(\mathrm{Y}-\hat{\mathrm{Y}})^{2}
\end{aligned}
$$

where:

$\mathrm{Y}$ - experimental value;

Y - value estimated by the model;

$\mathrm{n}$ - number of experimental observations; and

DF - degrees of freedom (number of observations minus the number of parameters of the model).

The mathematical model of liquid diffusion using the analytical solution for the cylindrical geometric form (Brooker et al., 1992), with eight-term approximation (Eq. 15), was adjusted to the experimental data of drying of pepper fruits, disregarding its volumetric contraction (Reis et al., 2011).

$$
\mathrm{RX}=\frac{\mathrm{X}-\mathrm{X}_{\mathrm{e}}}{\mathrm{X}_{\mathrm{i}}-\mathrm{X}_{\mathrm{e}}}=\sum_{\mathrm{n}=1}^{\infty} \frac{4}{\lambda_{\mathrm{n}}^{2}} \cdot \exp \left[-\frac{\lambda_{\mathrm{n}}^{2} \cdot \mathrm{D}_{\mathrm{ef}} \cdot \mathrm{t}}{\mathrm{r}}\right]
$$

where:

D - effective diffusion coefficient, $\mathrm{m}^{2} \mathrm{~s}^{-1}$;

$\lambda^{\text {ef }}$ - roots of the Bessel's equation of zero order;

$\mathrm{n}$ - number of terms;

r - equivalent sphere radius, $0.0048 \mathrm{~m}$; and

$\mathrm{t} \quad$ - time, s.

For the determination of the initial equivalent radius, defined as the radius of a sphere with volume equivalent to that of 'Cabacinha' pepper fruits (Mohsenin, 1986), four replicates of 25 fruits were used, which had the orthogonal axes (length, width and thickness) measured using a digital caliper with resolution of $0.01 \mathrm{~mm}$ (Corrêa et al., 2010).

In order to evaluate the influence of the drying temperature on the effective diffusion coefficient, the Arrhenius equation was adjusted according to the following expression:

$$
\mathrm{D}_{\text {ef }}=\mathrm{D}_{0} \cdot \exp \left(-\frac{\mathrm{E}_{\mathrm{a}}}{\mathrm{R} \cdot \mathrm{T}_{\mathrm{a}}}\right)
$$

where:

D - pre-exponential factor, $\mathrm{m}^{2} \mathrm{~s}^{-1}$;

$\mathrm{E}^{0}$ - activation energy, $\mathrm{kJ} \mathrm{mol}^{-1}$;

$\mathrm{R}^{\mathrm{a}} \quad$ - universal gas constant, $8.314 \mathrm{~kJ} \mathrm{~mol}^{-1} \mathrm{~K}^{-1}$; and

$\mathrm{T}$ a - absolute temperature, $\mathrm{K}$.

The thermodynamic properties (enthalpy, entropy and Gibbs free energy) related to the drying process of pepper fruits were calculated using the method described by the universal gas constant, through the following equations, respectively:

$$
\begin{gathered}
\Delta \mathrm{H}=\mathrm{E}_{\mathrm{a}}-\mathrm{R} \cdot \mathrm{T}_{\mathrm{a}} \\
\Delta \mathrm{S}=\mathrm{R} \cdot\left[\ln \left(\mathrm{D}_{0}\right)-\ln \left(\frac{\mathrm{k}_{\mathrm{B}}}{\mathrm{h}_{\mathrm{P}}}\right)-\ln \left(\mathrm{T}_{\mathrm{a}}\right)\right] \\
\Delta \mathrm{G}=\Delta \mathrm{H}-\mathrm{T}_{\mathrm{a}} \cdot \Delta \mathrm{S}
\end{gathered}
$$

where:

$\Delta \mathrm{H}$ - specific enthalpy, $\mathrm{J} \mathrm{mol}^{-1}$;

$\Delta \mathrm{S} \quad$ - specific entropy, $\mathrm{J} \mathrm{mol}^{-1} \mathrm{~K}^{-1}$;

$\Delta \mathrm{G}$ - Gibbs free energy, $\mathrm{J} \mathrm{mol}^{-1}$;

$\mathrm{k}_{\mathrm{B}} \quad$ - constant of Boltzmann, $1.38 \times 10^{-23} \mathrm{~J} \mathrm{~K}^{-1}$;

$\mathrm{h}_{\mathrm{p}} \quad$ - constant of Planck, $6.626 \times 10^{-34} \mathrm{~J} \mathrm{~s}^{-1}$; and

$\mathrm{T}_{\mathrm{a}}$ - absolute temperature, $\mathrm{K}$.

\section{Results AND Discussion}

The initial water content of 'Cabacinha' pepper fruits was approximately 6.038 (decimal, d.b.); on the other hand, the water contents at hygroscopic equilibrium, obtained at the end of the drying process at the temperatures of $60,70,80,90$ and $100{ }^{\circ} \mathrm{C}$, were $0.069,0.066,0.051,0.017$ and 0.021 (decimal, d.b.), respectively. The reduction in equilibrium water content with the increase in drying air temperature was also observed for fruits of green bell pepper (Silva et al., 2008), 'Pimentade-cheiro' (Pontes et al., 2009) and 'Cumari-do-Pará pepper (Reis et al., 2011).

The statistical parameters used for the comparison between the models adjusted to the experimental data of drying of pepper fruits, under the different drying conditions, are shown in Table 2.

The analyzed models showed coefficients of determination $\left(\mathrm{R}^{2}\right)$ above 0.9792 , standard deviation of estimate (SE) below 0.079 (decimal) and residual sum of squares (RSS) lower than 0.604 (decimal, x 10-2).

According to Draper \& Smith (1998), the lower the value of SE, the better will be the quality of the fit in relation to the experimental data. In the present study, this same selection criterion was also adopted for RSS.

Among the adjusted models, Midilli (Eq. 6) showed the highest coefficients of determination $\left(\mathrm{R}^{2}>0.9990\right)$ and the lowest standard deviations of estimate $(\mathrm{SE}<0.018)$ and residual sum of squares (RSS $<0.029 \times 10^{-2}$ ), thus proving to be an adequate fit to the experimental data of drying of pepper fruits under the different drying conditions evaluated. 
Table 2. Coefficients of determination $\left(R^{2}\right)$, standard deviation of estimate (SE, decimal), residual sum of squares (RSS, decimal $\times 10^{-2}$ ) and behavior with respect to the residual distribution (RD) for the models adjusted to the experimental data of drying the 'Cabacinha' pepper fruits

\begin{tabular}{|c|c|c|c|c|c|c|c|c|c|c|c|c|}
\hline Models & $\mathrm{R}^{2}$ & SE & RSS & RD & $\overline{\mathrm{R}^{2}}$ & SE & RSS & RD & $\mathbf{R}^{2}$ & SE & RSS & RD \\
\hline & \multicolumn{4}{|c|}{$60^{\circ} \mathrm{C}$} & \multicolumn{4}{|c|}{$70^{\circ} \mathrm{C}$} & \multicolumn{4}{|c|}{$80^{\circ} \mathrm{C}$} \\
\hline Approximation of Diffusion & 0.9977 & 0.024 & 0.054 & $\mathrm{BD}$ & 0.9944 & 0.041 & 0.154 & $\mathrm{BD}$ & 0.9908 & 0.054 & 0.270 & $\mathrm{BD}$ \\
\hline Two-Term & 0.9846 & 0.062 & 0.361 & $\mathrm{BD}$ & 0.9855 & 0.066 & 0.397 & $\mathrm{BD}$ & 0.9974 & 0.030 & 0.078 & $\mathrm{RD}$ \\
\hline Logarithmic & 0.9979 & 0.023 & 0.050 & $\mathrm{BD}$ & 0.9957 & 0.036 & 0.119 & $\mathrm{BD}$ & 0.9931 & 0.047 & 0.203 & $\mathrm{BD}$ \\
\hline Midilli & 0.9991 & 0.015 & 0.020 & $\mathrm{RD}$ & 0.9990 & 0.018 & 0.029 & $\mathrm{RD}$ & 0.9991 & 0.017 & 0.026 & $\mathrm{RD}$ \\
\hline Modified Midilli & 0.9990 & 0.016 & 0.025 & RD & 0.9988 & 0.019 & 0.033 & $\mathrm{RD}$ & 0.9989 & 0.019 & 0.032 & $\mathrm{RD}$ \\
\hline Newton & 0.9797 & 0.070 & 0.477 & $\mathrm{BD}$ & 0.9792 & 0.076 & 0.569 & $\mathrm{BD}$ & 0.9793 & 0.079 & 0.604 & $\mathrm{BD}$ \\
\hline Page & 0.9969 & 0.028 & 0.074 & $\mathrm{RD}$ & 0.9980 & 0.024 & 0.055 & $\mathrm{RD}$ & 0.9987 & 0.020 & 0.038 & $\mathrm{RD}$ \\
\hline Modified Page & 0.9969 & 0.028 & 0.074 & $\mathrm{RD}$ & 0.9980 & 0.024 & 0.055 & $\mathrm{RD}$ & 0.9987 & 0.020 & 0.038 & $\mathrm{RD}$ \\
\hline Verna & 0.9842 & 0.062 & 0.372 & $\mathrm{BD}$ & 0.9836 & 0.070 & 0.449 & $\mathrm{BD}$ & 0.9840 & 0.072 & 0.468 & $\mathrm{BD}$ \\
\hline \multirow[t]{2}{*}{ Wang and Singh } & 0.9988 & 0.017 & 0.028 & $\mathrm{BD}$ & 0.9973 & 0.028 & 0.075 & $\mathrm{BD}$ & 0.9962 & 0.034 & 0.111 & $\mathrm{BD}$ \\
\hline & \multicolumn{4}{|c|}{$90^{\circ} \mathrm{C}$} & \multicolumn{4}{|c|}{$100^{\circ} \mathrm{C}$} & & & & \\
\hline Approximation of diffusion & 0.9889 & 0.060 & 0.329 & $\mathrm{BD}$ & 0.9888 & 0.061 & 0.329 & $\mathrm{BD}$ & - & - & - & - \\
\hline Two-term & 0.9875 & 0.065 & 0.371 & BD & 0.9883 & 0.064 & 0.345 & BD & - & - & - & - \\
\hline Logarithmic & 0.9916 & 0.052 & 0.248 & $\mathrm{BD}$ & 0.9916 & 0.053 & 0.247 & $\mathrm{BD}$ & - & - & - & - \\
\hline Midilli & 0.9992 & 0.017 & 0.025 & $\mathrm{RD}$ & 0.9992 & 0.017 & 0.025 & $\mathrm{RD}$ & - & - & - & - \\
\hline Modified Midilli & 0.9990 & 0.018 & 0.031 & $\mathrm{RD}$ & 0.9990 & 0.018 & 0.029 & $\mathrm{RD}$ & - & - & - & - \\
\hline Newton & 0.9803 & 0.078 & 0.582 & BD & 0.9812 & 0.076 & 0.552 & $\mathrm{BD}$ & - & - & - & - \\
\hline Page & 0.9989 & 0.019 & 0.033 & $\mathrm{RD}$ & 0.9990 & 0.018 & 0.030 & $\mathrm{RD}$ & - & - & - & - \\
\hline Modified Page & 0.9989 & 0.019 & 0.033 & $\mathrm{RD}$ & 0.9990 & 0.018 & 0.030 & $\mathrm{RD}$ & - & - & - & - \\
\hline Verna & 0.9846 & 0.071 & 0.454 & BD & 0.9883 & 0.076 & 0.510 & $\mathrm{BD}$ & - & - & - & - \\
\hline Wang and Singh & 0.9944 & 0.042 & 0.167 & $\mathrm{BD}$ & 0.9927 & 0.048 & 0.217 & $\mathrm{BD}$ & - & - & - & - \\
\hline
\end{tabular}

$\mathrm{BD}$ - Biased distribution; RD - Random distribution

In the analysis of drying kinetics of 'Cumari-do-Pará' pepper (Capsicum chinense Jacquin), at the temperatures of 45 , 55 and $65^{\circ} \mathrm{C}$ and 'Cambuci' pepper (Capsicum baccatum) at the temperatures of 40,50 and $60^{\circ} \mathrm{C}$, Reis et al. (2011) and Derlan et al. (2013) also observed that the Midilli model showed the best fit to the experimental data.

As to the residual distribution (Table 2), only the models of Midilli (Eq. 6), modified Midilli (Eq. 7), Page (Eq. 9) and modified Page (Eq. 10) showed random residual distribution for the five temperatures studied.

The residual distribution was considered as random when the values of residues were close to the horizontal line, around zero, and did not form defined figures, indicating that there is no tendency in the results. When the residues showed biased distribution, the model was considered as inadequate to represent the studied phenomenon. However, for having

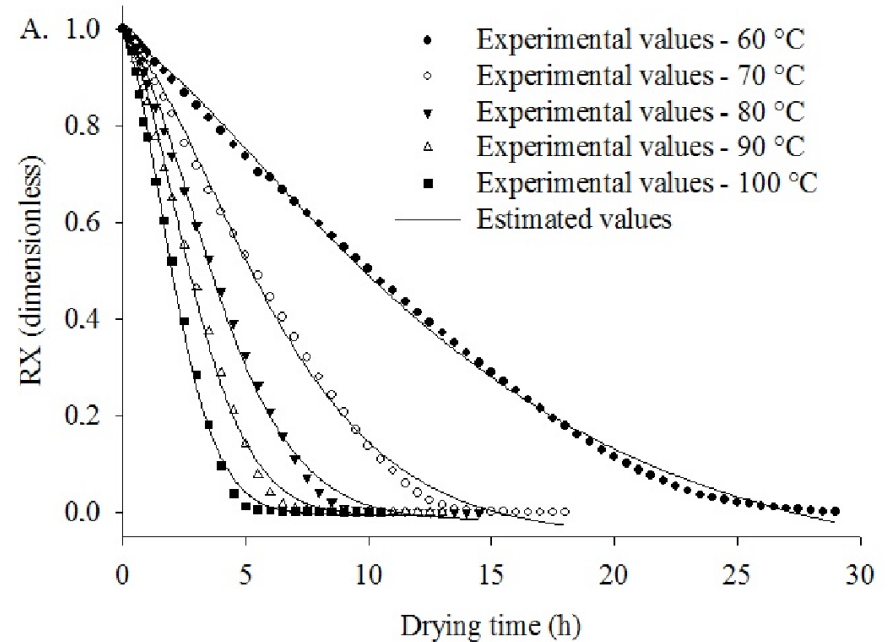

random residual distribution and the best statistical parameters $\left(\mathrm{R}^{2}\right.$, SE and RSS) for all the studied temperatures (Table 2), the Midilli model (Eq. 6) was selected to represent the drying kinetics of 'Cabacinha' pepper fruits for the temperatures of $60,70,80,90$ and $100{ }^{\circ} \mathrm{C}$ (Figure 1A).

According to Figure $1 \mathrm{~A}$, the times necessary for pepper fruits to reach the water contents at hygroscopic equilibrium were $29,18,14.5,13$ and $10.5 \mathrm{~h}$, for the temperatures of 60 , $70,80,90$ and $100{ }^{\circ} \mathrm{C}$, respectively. Similar behaviors were observed by Reis et al. (2011) in studies with 'Cumari-doPará pepper and by Moraes et al. (2013), studying 'Dedode-moça' pepper.

Still in Figure 1B, the maximum values $(0.402,0.728,0.926$, 1.312 and $2.010 \mathrm{~kg} \mathrm{~kg}^{-1} \mathrm{~h}^{-1}$ ) of water removal rate (WRR) occurred after 5.5, 2.5, 1.5, 1.5 and $0.8 \mathrm{~h}$ of drying, respectively for the temperatures of $60,70,80,90$ and $100{ }^{\circ} \mathrm{C}$. The increase

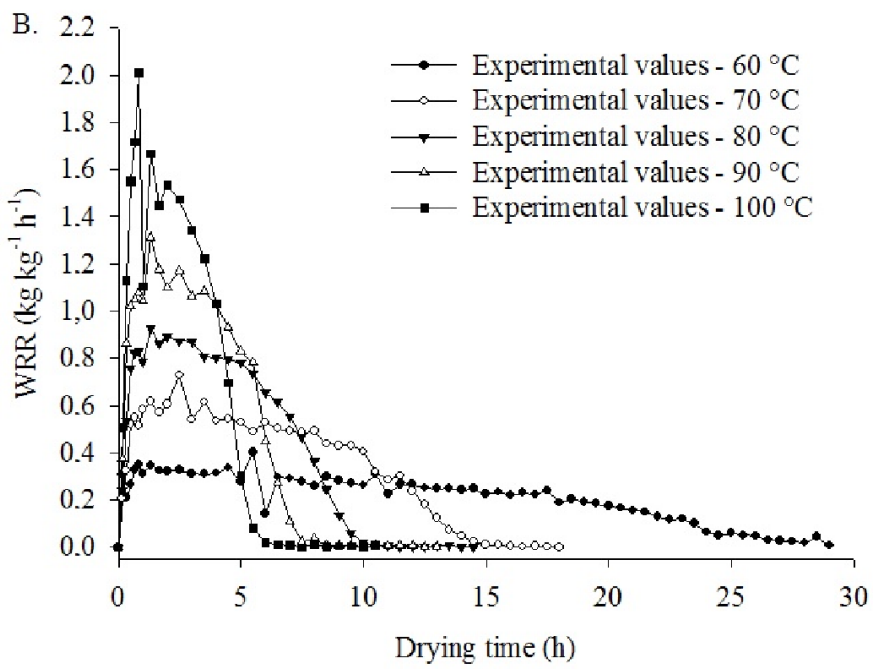

Figure 1. Experimental values and values estimated by the Midilli model for the moisture ratio (RX; $A)$ and water removal rate (WRR, B) as a function of the drying time of 'Cabacinha' pepper fruits 
in drying temperature reduced the time necessary to reach the highest WRR values, evidencing the increment in the water potential gradient existing between the fruits and the drying air. The influence of air temperature on water removal rate was also reported by Corrêa et al. (2001).

The parameters of the Midilli model for each drying temperature and the respective equations are shown in Table 3. The equations used to estimate each coefficient as a function of the drying air temperature showed high coefficients of determination $\left(\mathrm{R}^{2}>0.9342\right)$ and regression coefficients significant at 0.01 probability level by t-test. In addition, only the "a" coefficient did not show variation tendency as a function of temperature; thus, its mean value was used $(\mathrm{a}=0.979)$.

The values of the effective diffusion coefficient and the Arrhenius representation as a function of the drying temperature of pepper fruits are shown in Figure 2.

In Figure 2, the increase in drying temperature promoted increment in the values of the effective diffusion coefficient and reduction in the Arrhenius representation. According to Goneli et al. (2014), when temperature increases, water viscosity decreases and, since viscosity is a measurement of fluid resistance to flowing, variation in this property lead to alterations in water diffusion in the capillaries of pepper fruits.

For the drying of 'Cabacinha' pepper fruits in the temperature range of 60 to $100{ }^{\circ} \mathrm{C}$, the effective diffusion coefficient ranged from $4.07 \times 10^{-9}$ to $21.42 \times 10^{-9} \mathrm{~m}^{2} \mathrm{~s}^{-1}$, respectively. These values are considered as high compared with those obtained by Srinivasakannan \& Balasubramanian (2009) for green pepper $\left(1.95 \times 10^{-11}\right.$ to $\left.7.00 \times 10^{-11} \mathrm{~m}^{2} \mathrm{~s}^{-1}\right)$, Reis et al. (2011) for 'Cumari-do-Pará' pepper $\left(2.29 \times 10^{-11}\right.$ to $2.57 \mathrm{x}$ $\left.10^{-11} \mathrm{~m}^{2} \mathrm{~s}^{-1}\right)$ and Derlan et al. (2013) for 'Cumari-do-Pará' (2.39 $\mathrm{x} 10^{-10}$ to $\left.5.08 \times 10^{-10} \mathrm{~m}^{2} \mathrm{~s}^{-1}\right)$ in the temperature ranges of 50 to 70,45 to 65 and 40 to $60{ }^{\circ} \mathrm{C}$, respectively.

The difference between the values of the effective diffusion coefficient for the different types of pepper is due to physical characteristics (Martins et al., 2015), water content and forms of processing of each fruit (Derlan et al., 2013). Rizvi (1995) points out that the diffusion coefficient is also dependent on drying air temperature, variety and composition of the materials, besides other factors.

As observed in Figure 2B, both the effective diffusion coefficient and the Arrhenius representation can be expressed by linear equations, thus agreeing with the results obtained by Kaleemullah \& Kailappan (2006), Reis et al. (2011), Derlan et al. (2013) and Martins et al. (2015).

According to Goneli et al. (2014), the slope of the Arrhenius representation provides the E/R relationship, while its intersection with the $\mathrm{Y}$-axis indicatès the value of $\mathrm{D}$; thus, the activation energy (Eq. 21) of the water diffusion of 'Cabacinha' pepper fruits was equal to $36.09 \mathrm{~kJ} \mathrm{~mol}^{-1}$. This value is consistent with those found by Kaleemullah \& Kailappan (2006) for red pepper $\left(37.76 \mathrm{~kJ} \mathrm{~mol}^{-1}\right)$ and Vega et al. (2007) for red bell pepper $\left(39.70 \mathrm{~kJ} \mathrm{~mol}^{-1}\right)$.

$$
D_{\text {ef }}=\left(2.468 \cdot 10^{-3}\right) \cdot \exp \left(-\frac{36,093.144}{R \cdot T_{a}}\right)
$$

Table 3. Midilli model coefficients and adjusted equations as a function of drying air temperature for 'Cabacinha' pepper fruits

\begin{tabular}{|c|c|c|c|c|c|c|c|}
\hline \multirow{2}{*}{ Coefficients } & \multicolumn{5}{|c|}{ Temperature $\left({ }^{\circ} \mathrm{C}\right)$} & \multirow[b]{2}{*}{ Equations } & \multirow[b]{2}{*}{$\mathbf{R}^{2}$} \\
\hline & 60 & 70 & 80 & 90 & 100 & & \\
\hline a & 0.9778 & 0.9814 & 0.9779 & 0.9765 & 0.9803 & $a=0.979^{\star}$ & ns \\
\hline k & 0.0267 & 0.0503 & 0.0797 & 0.1235 & 0.2097 & $k=0.001^{* *} \cdot \exp \left(0.048^{* \star} \cdot T\right)$ & 0.9829 \\
\hline $\mathrm{n}$ & 1.3754 & 1.5455 & 1.6604 & 1.6950 & 1.6713 & $\mathrm{n}=-1.573^{\star *}+0.073^{\star *} \cdot T+\left(-4.054^{\star \star} \cdot 10^{-4}\right) \cdot T^{2}$ & 0.9342 \\
\hline b & -0.0029 & -0.0021 & -0.0010 & -0.0006 & -0.0005 & $\mathrm{~b}=-0.024^{* *}+\left(5 \cdot 049^{* *} \cdot 10^{-4}\right) \cdot T+\left(-2 \cdot 685^{* *} \cdot 10^{-6}\right) \cdot T^{2}$ & 0.9787 \\
\hline
\end{tabular}

${ }^{*}$ Mean value; ${ }^{* \star}$ Significant at 0.01 by t-test; ${ }^{\text {ns Not significant }}$
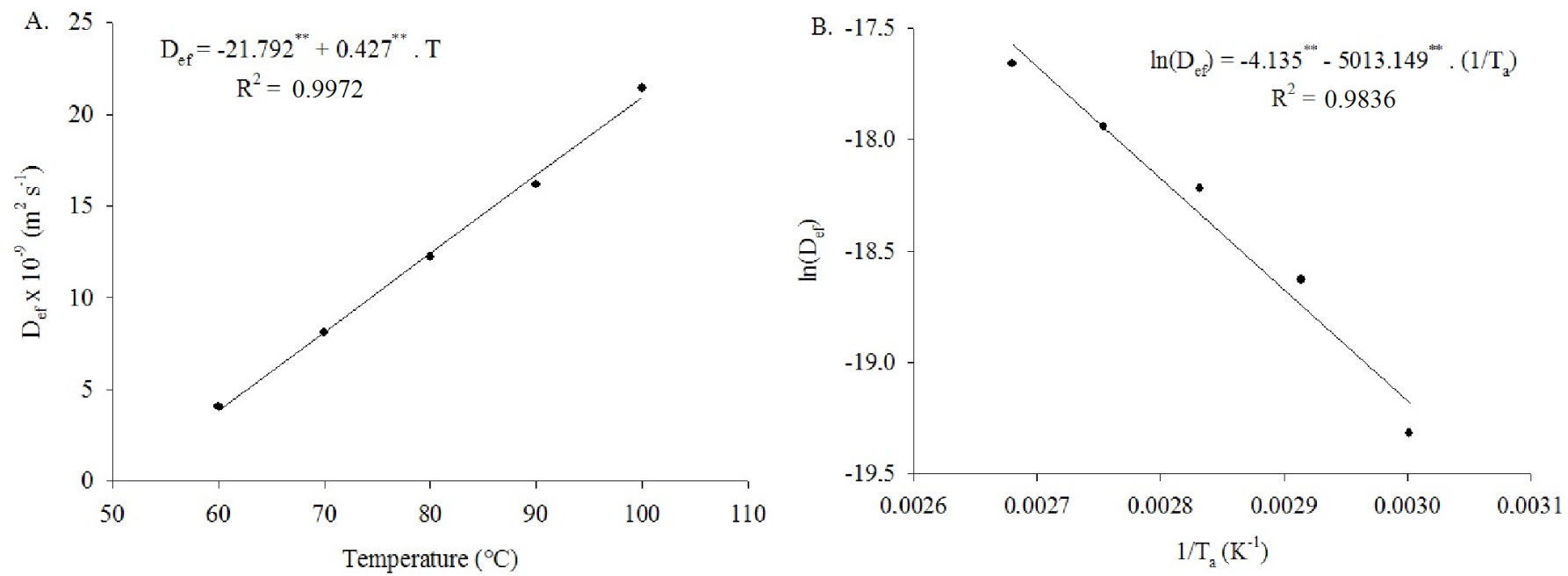

${ }^{* *}$ Significant at 0.01 by t-test

Figure 2. Mean experimental values and estimated values of the effective diffusion coefficient (D ; A) and Arrhenius representation for the effective diffusion coefficient $(\ln (D)$; B) as a function of the drying air temperature of 'Cabacinha' pepper fruits 
The activation energy is related to the amount of energy necessary to trigger the process of water diffusion (Martins et al., 2015); thus, the lower the activation energy, the higher will be the water diffusivity of the product, i.e., the lower will be the energy necessary to transform liquid free water into vapor (Corrêa et al., 2010).

The mean values of enthalpy, entropy and Gibbs free energy as a function of drying temperature of pepper fruits are shown in Table 4.

Enthalpy decreased from $333.23 \times 10^{2}$ to $329.91 \times 10^{2} \mathrm{~J} \mathrm{~mol}^{-1}$ with the increase in temperature from 60 to $100{ }^{\circ} \mathrm{C}$ (Table 4). Corrêa et al. (2010) obtained similar values for the drying of coffee (Coffea arabica L.) at the temperatures of 35, 45 and 55 ${ }^{\circ} \mathrm{C}$, with enthalpy variations of $358.28 \times 10^{2}, 357.45 \times 10^{2}$ and $356.62 \times 10^{2} \mathrm{~J} \mathrm{~mol}^{-1}$, respectively. These authors concluded that this characteristic is an indication that lower amount of energy is required for the drying process to occur at higher temperatures.

Entropy, which is related to the degree of excitation and spatial arrangement of water molecules in relation to the product (Jideane \& Mptokawana, 2009; Goneli et al., 2010), ranged from -295.75 to $-296.69 \mathrm{~J} \mathrm{~mol}^{-1} \mathrm{~K}^{-1}$ for the temperature range of 60 to $100{ }^{\circ} \mathrm{C}$ (Table 4). Thus, the lowest values of entropy for the highest temperatures indicate that, under this condition, there is lower excitation of water molecules, i.e., there is a higher degree of order between water molecules and the pepper fruits. In addition, the negative values of entropy can be attributed to the existence of chemical alteration or modifications in the structure of the product during the drying process (Corrêa et al., 2010).

Gibbs free energy increased from $131.85 \times 10^{3}$ to $143.70 \mathrm{x}$ $10^{3} \mathrm{~J} \mathrm{~mol}^{-1}$, with the increase in temperature from 60 to 100 ${ }^{\circ} \mathrm{C}$ (Table 4); positive values indicate that drying is a nonspontaneous process, i.e., it requires an additional energy from the environment surrounding the product for the reaction to occur (Corrêa et al., 2010).

Table 4. Enthalpy $(\Delta \mathrm{H})$, entropy $(\Delta \mathrm{S})$ and Gibbs free energy $(\Delta \mathrm{G})$ as a function of drying air temperature of 'Cabacinha' pepper fruits

\begin{tabular}{lccccc}
\hline Thermodynamic & \multicolumn{5}{c}{ Temperature ( $\left.{ }^{\circ} \mathbf{C}\right)$} \\
\cline { 2 - 6 }$\quad \mathbf{p r o p e r t i e s}$ & $\mathbf{6 0}$ & $\mathbf{7 0}$ & $\mathbf{8 0}$ & $\mathbf{9 0}$ & $\mathbf{1 0 0}$ \\
$\Delta \mathrm{H} \times 10^{2}\left(\mathrm{~J} \mathrm{~mol}^{-1}\right)$ & 333.233 & 332.402 & 331.571 & 330.739 & 329.908 \\
$\Delta \mathrm{S}\left(\mathrm{J} \mathrm{mol}^{-1} \mathrm{~K}^{-1}\right)$ & -295.751 & -295.997 & -296.235 & -296.468 & -296.693 \\
$\Delta \mathrm{G} \times 10^{3}\left(\mathrm{~J} \mathrm{~mol}^{-1}\right)$ & 131.853 & 134.811 & 137.773 & 140.736 & 143.702 \\
\hline
\end{tabular}

\section{Conclusions}

1. The Midilli model showed the best fit to the experimental data of drying of 'Cabacinha' pepper fruits and was selected to represent this phenomenon.

2. The increase in drying temperature promoted a reduction in the time necessary for the fruits to reach the water content at hygroscopic equilibrium.

3. With the increase in drying temperature, there was an increase in effective diffusion coefficient and Gibbs free energy and a reduction in the values of enthalpy and entropy.

4. The activation energy for the drying of pepper fruits at the temperatures of $60,70,80,90$ and $100^{\circ} \mathrm{C}$ was $36.09 \mathrm{~kJ} \mathrm{~mol}^{-1}$.

\section{Literature Cited}

ASABE - American Society of Agricultural and Biological Engineers. Moisture measurement - forages: Standard S358.2 DEC1988, R2008. In: American Society of Agricultural and Biological Engineers (ed.). Standards, Engineering Practices, and Data. St. Joseph: ASABE, 2010. p.684-685.

Brooker, D. B.; Bakker-Arkema, F. W.; Hall, C. W. Drying and storage of grains and oilseeds. Westport: The AVI Publishing Company, 1992. 450p.

Corrêa, P. C.; Machado, P. F.; Andrande, E. T. Cinética de secagem e qualidade de grãos de milho-pipoca. Ciência e Agrotecnologia, v.25, p.134-142, 2001.

Corrêa, P. C.; Oliveira, G. H. H.; Botelho, F. M.; Goneli, A. L. D.; Carvalho, F. M. Modelagem matemática e determinação das propriedades termodinâmicas do café (Coffea arabica L.) durante o processo de secagem. Revista Ceres, v.57, p.595-601, 2010. http:// dx.doi.org/10.1590/S0034-737X2010000500005

Dagnoko, S.; Yaro, Diarisso, N.; Sanogo, P. N.; Adetula, O.; DoloNantoumé, A.; Gamby-Touré, K.; Traoré-Théra, A.; Katilé, S.; Diallo-Ba, D. Overview of pepper (Capsicum spp.) breeding in West Africa. Agrican Journal of Agricultural Research, v.8, p.1108-1114, 2013.

Draper, N. R.; Smith, H. Applied regression analysis. New York: John Wiley \& Sons, 1998. 712p.

Derlan, J. M.; Silva, F. S.; Porto, A. G.; Leite, A. L. M. P.; Pastro, D. C. Análise da cinética de secagem de pimenta Cambuci em diferentes temperaturas e formas de processamento. Enciclopédia Biosfera, v.9, p.97-107, 2013.

Goneli, A. L. D.; Corrêa, P. C.; Magalhães, F. E. A.; Baptestini, F. M. Contração volumétrica e forma dos frutos de mamona durante a secagem. Acta Scientiarum. Agronomy, v.33, p.1-8, 2011. http:// dx.doi.org/10.4025/actasciagron.v33i1.4629

Goneli, A. L. D.; Corrêa, P. C.; Oliveira, G. H. H.; Botelho, F. M. Water desorption and thermodynamic properties of okra seeds. Transactions of the ASAE, v.53, p.191-197, 2010. http://dx.doi. org/10.13031/2013.29486

Goneli, A. L. D.; Vieira, M. C.; Vilhasanti, H. C. B.; Gonçalves, A. A. Modelagem matemática e difusividade efetiva de folhas de aroeira durante a secagem. Pesquisa Agropecuária Tropical, v.44, p.5664, 2014. http://dx.doi.org/10.1590/S1983-40632014000100005

Henz, G. P.; Moretti, C. L. Colheita e pós-colheita. In: Ribeiro, C. S. C.; Lopes, C. A.; Carvalho, S. I. C.; Henz, G. P.; Reifschneider, F. J. B. Pimentas Capsicum. Brasília: Embrapa Hortaliças, 2008. p.149-156.

Jideani, V. A.; Mpotokwana, A, S. M. Modeling of water absorption of Botswanabambara varieties using Peleg's equation. Journal of Food Engineering, v.92, p.182-188, 2009. http://dx.doi. org/10.1016/j.jfoodeng.2008.10.040

Kaleemullah, S.; Kailappan, R. Moisture sorption isotherms of red chillies. Biosystems Engineering, v.88, p.95-104, 2004. http:// dx.doi.org/10.1016/j.biosystemseng.2004.01.003

Kaleemullah, S.; Kailappan, R. Modelling of thin-layer drying kinetics of red chillies. Journal of Food Engineering, v.76, p.531-537, 2006. http://dx.doi.org/10.1016/j.jfoodeng.2005.05.049

Martins, E. A. S.; Lage, E. Z.; Goneli, A. L. D.; Hartmann Filho, C. P.; Lopes, J. G. Cinética de secagem de folhas de timbó (Serjania marginata Casar). Revista Brasileira de Engenharia Agrícola e Ambiental, v.19, p.238-244, 2015. http://dx.doi.org/10.1590/18071929/agriambi.v19n3p238-244 
Mohsenin, N. N. Physical properties of plant and animal materials. New York: Gordon and Breach Publishers. 1986. 841p.

Moraes, I. C. F.; Sobral, P. J. A.; Brano, I. G.; Ré, T. B.; Gomide, C. A. Dehydration of "dedo de moça" pepper: kinetics and phytochemical concentration. Ciência e Tecnologia de Alimentos, v.33, p.134-141, 2013. http://dx.doi.org/10.1590/S010120612013000500020

Pontes, S. F. O.; Santos, C. T.; Bonomo, R. C. F.; Pontes, L. V.; Fontan, R. C. I. Determinação das curvas de secagem em camada delgada de pimenta de cheiro (Capsicum chinense) a diferentes temperaturas. Revista Brasileira de Produtos Agroindustriais, v.11, p.143-148, 2009. http://dx.doi.org/10.15871/1517-8595/ rbpa.v11n2p143-148

Reis, R. C.; Barbosa, L. S.; Lima, M. L.; Reis, J. S.; Devilla, I. A.; Ascheri, D. P. R. Modelagem matemática da secagem da pimenta Cumari do Pará. Revista Brasileira de Engenharia Agrícola e Ambiental, v.15, p.347-353, 2011. http://dx.doi.org/10.1590/ S1415-43662011000400003
Rizvi, S. S. H. Thermodynamic properties of foods in dehydration. In: Rao, M. A.; Rizvi, S. S. H. Engineering properties of foods. New York: Academic Press, 1995. p.223-309.

Santos, J. A. B.; Silva, G. F.; Pagani, A. A. C. Estudo da cinética de secagem da pimenta malagueta (Capsicum spp) cultivada no estado de Sergipe. Revista GEINTEC, v.2, p.465-471, 2012. http:// dx.doi.org/10.7198/S2237-0722201200050004

Silva, A. S.; Almeida, F. de A. C.; Silva, F. L. H. da; Dantas, H. J.; Lima, E. E. de. Desidratação e efeito de pré-tratamentos no extrato seco do pimentão verde. Revista Brasileira de Produtos Agroindustriais, v.10, p.27-34, 2008. http://dx.doi.org/10.15871/1517-8595/rbpa. v10n1p27-34

Srinivasakannan, C.; Balasubramanian, N. Estimation of diffusion parameters in fluidized bed drying. Advanced Powder Technology, v.20, p.390-394, 2009. http://dx.doi.org/10.1016/j.apt.2009.06.003

Vega, A.; Fito, P.; Andrés, A.; Lemus, R. Mathematical modeling of hot-air drying kinetics of red bell pepper (var. Lamuyo). Journal of Food Engineering, v.79, p.1460-1466, 2007. http://dx.doi. org/10.1016/j.jfoodeng.2006.04.028 